\title{
Potential Cluster Regions for Manufacturing Small and Medium Enterprises in Khulna City of Bangladesh: A Spatial Examination
}

\author{
S M Towhidur Rahman, Ahsanul Kabir
}

\begin{abstract}
Industrialization is considered as the main path towards urbanization and economic development. Small and medium enterprises (SMEs) are the major contributor to the industrialization in many countries across the world. Cluster approach has gained extensive acceptance among academics and policy makers as an effective development strategy both for an industry and a region. This study thus aims to identify the potential cluster regions (PCRs) for manufacturing SMEs in Khulna city of Bangladesh since such identification is an important first step for cluster-based development strategy. Locating and mapping key manufacturing SMEs and exploring their spatial pattern are the major objectives of the study. The study concentrates on applying geo-statistical analysis such average nearest neighbour index, kernel density plot and SME distribution mapping using GIS to find the spatial pattern of the industries in the study area. The study depicted a clustered spatial pattern and uneven distribution of the SMEs across different wards of the city.
\end{abstract}

Index Terms: Bangladesh, Cluster, Nearest neighbour index, SME, Spatial analysis.

\section{INTRODUCTION}

Industrialization is often considered as the main path towards urbanization and economic growth of a region [1]. A positive correlation between industrialization, urbanization and economic growth had been evident in numerous studies done across the world including Bangladesh [2]- [4]. Development of industrial clusters is often recognized as an engine of regional economic development. Cluster strategy had gained heightened attention from academics and policymakers around the world as an alternative and effective strategy for fostering competitiveness and economic development at different levels including firms, region and even a country in the past decade [5], [6]. Small and medium enterprises (SMEs) play a crucial role in the process of industrialization and urbanization since they comprise the major share of the industrial units and employment both in developed and developing countries [7], [8]. Hence the development of manufacturing SME clusters had been recognized as one of the dynamic approaches to advance regional development [9]. Cluster development is considered

Revised Manuscript Received on September 22, 2019.

S M Towhidur Rahman, Business Administration Discipline, Khulna University, Khulna 9208, Bangladesh. email: towhid_ku_97@yahoo.com

Dr. Ahsanul Kabir, Urban and Rural Planning Discipline, Khulna University, Khulna 9208, Bangladesh.email:ahsanul_kabir@hotmail.com as one of the solutions to overcome the size limitations of SMEs and as an important tool to provide these enterprises with a competitive advantage [10]. Researches also suggest that industry clusters grew out of scratch are less likely to grow and succeed and cluster-based strategy tend to succeed in locations where there is a potential cluster of industries built around some kind of locational benefits [11]. So, for successful implementation of cluster-based development strategy, identifying potential cluster region (PCR) is the important first step since cluster policy requires capitalizing the potentials arising from existing or emerging competencies and specialities of a region for their development [12]. Although CBED has gained popularity among practitioners, there are large disagreements among them regarding the appropriate approach to identifying clusters. Non-spatial techniques like location quotient (LQ), shift-share analysis, input-output analysis and expert opinion are frequently applied for cluster identification those often fail to explain the spatial link between the cluster and the locations [13]. The recent development in the geospatial tools allows policymakers to use different spatial statistical tools to locate the spatial pattern of various incidences and the reasons for them. GIS technology has recently been used for solving a variety of spatially-based problems like economic impact analysis, PCR identification and making other spatial policies by policymakers around the world [14].

Bangladesh demonstrates relatively low levels of industrial and urban development compared to other more developed countries of Asia [15]. Currently, the industry sector contributes $33.66 \%$ (with growth over 10\%) to the Country's GDP most of which $(22.85 \%)$ attributed to the performance of manufacturing sector [16]. Such growth mainly came through growing numbers of Small and Medium Enterprises (SMEs) across the country. Government of Bangladesh prioritized cluster based industrialization for achieving development target set in Vision 2021 [17]. But very few initiatives and studies are found to date both from government and academics for identifying and developing industry clusters in the country. To fill this knowledge gap in the context of Bangladesh, this study aims to identify the potential cluster regions of manufacturing SMEs taking Khulna Metropolitan City, the third largest city of Bangladesh as the study area. The study expects to add to the inadequate literature related to SME cluster identification

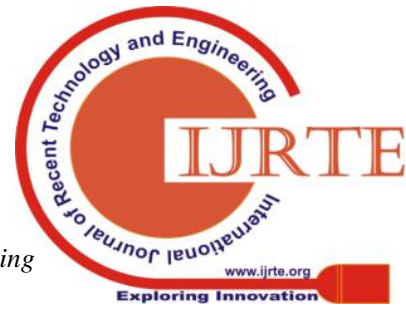


and economic agglomeration in Bangladesh. Through the application of GIS Statistical tools, the study aims to find potential cluster regions (PCR) in the city which would assist development and city planners to make informed decisions in implementing CBED strategy for the development of the industry and the region.

\section{LITERATURE REVIEW}

Cluster-based economic development (CBED) strategy has become popular as an alternative development strategy in the field of industry and regional economic development in recent decades [18]. The focus of this strategy is to enhance productivity, innovativeness, and competitiveness of industries and regions reflecting a new way of endogenous development. [5] argued that cluster of firms drives up competitiveness through offering a number of benefits including better information, powerful incentives, intimate relationship and others that boost productivity and innovativeness due to geographic, cultural and institutional proximity. Although the cluster is a common economic phenomenon, there is no common definition of it. An industry cluster is defined as a collection of firms, related institutions and other economic entities which are located close to one another with a view to take productive advantages from their proximity and interrelations [19]. In other way, cluster denotes geographical and sectoral concentration of firms that generates collective efficiency for firms which results in combination from external economies (unplanned gains due to proximity e.g. access to larger market, availability of skilled labour, knowledge diffusion) and joint action i.e. planned gains arising from collaborative actions [20]. [21] argued that geographic proximity of firms is not sufficient to form a cluster and there must be active channels for business transactions, dialogue, and communication among the firms to produce synergy. Thus geographic proximity and collaborative relationships among the partners are two main components of cluster policy [10].

According to [22] cluster formation requires a foundation which often is built around locational advantages of a region independently of any government initiative. The author also recommended for identifying clusters presence first and then taking steps to remove obstacles and inefficiencies that impede productivity and innovativeness for upgrading those clusters. Thus, CBED process starts with finding potential cluster regions (PCR) through cluster mapping (the creation of systematic datasets on cluster presence across many regions) [11], [14], [18]. A PCR is defined as a geographic agglomeration of firms having potentials to be a cluster. Identification of PCRs increases the efficiency of cluster projects through eliminating those areas which lack a critical mass of firms required for cluster success [14]. But one issue must be in consideration while cluster identification that PCRs are based on spatial concentrations of firms only and cannot delineate interrelations among firms and hence is not sufficient to identify clusters. A better result could be achieved in identifying cluster by applying both spatial and non-spatial techniques in combination.
Applications of Geographic Information System (GIS) and spatial statistical tools have recently gained the attention of researchers and policymakers in solving a variety of spatially based problems. Spatial statistical techniques have been applied by practitioners in different fields to describe and predict geospatial patterns of various events and incidences including road accidents [23], crime [24], industry locations [15], and human settlement [25] and spatial distribution mapping, nearest neighbour analysis, kernel density estimation, spatial autocorrelation and hot spot analysis are few to name among the spatial tools frequently used by practitioners.

Even though identification of industry cluster and adopting cluster-based policy is considered as important for economic development agenda of the country, very few studies had been conducted in Bangladesh in this regard and applying GIS and spatial statistical tools are even fewer. This study thus applied Geospatial tools based on point data collected through a survey of manufacturing SMEs to locate the potential cluster regions as an important step in industry development.

\section{METHODOLOGY}

This study is mainly based on primary data in the absence of publicly available data regarding the numbers, categories, and locations of manufacturing SMEs in Khulna City Corporation area. Manufacturing SMEs are defined as manufacturing units which are not a public limited company and are employing 1-250 employees [26]. A city-wide walking survey was conducted using a tally sheet, on the major roads of the city to locate the manufacturing SMEs, put tally marks and note location description (e.g. holding number or identifiable landmarks) on separate tally sheet assigned for each road or location. Moreover, the snowballing technique was applied to locate firms whereby entrepreneurs were asked to identify locations of similar firms as conventional wisdom suggests that entrepreneurs usually have information about their competitors and their locations. Then applying GIS mapping tools the location data were plotted on the map of Khulna City Corporation which generated location coordinates (as point feature) for each SME for further spatial analysis. This survey was conducted between February 2018 and June 2018.

Kernel Density plot was generated for each category of manufacturing SMEs to show the distribution of points in terms of distance from two important spatial variables: major roads and river. Average nearest neighbour ratio was computed for different categories of SMEs to depict whether the firms are geographically clustered or dispersed. This technique measures the distance between each feature centroid (point feature) and its nearest neighbour feature centroid. Then all these distances are averaged and compared with the average distance of a hypothetical random distribution. If the average distance of observed distribution is less than that of hypothetical random distribution, the features are considered as clustered and if the average distance is higher than that of hypothetical distribution, it is

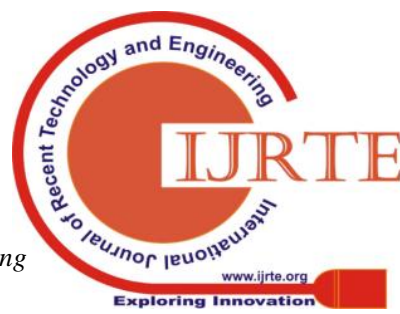


considered dispersed. In another way, if the average nearest neighbour ratio or ANN Index is less than 1, the features distribution exhibits clustered pattern and an index greater than 1 indicates a dispersed pattern [27]. A choropleth map was also generated to show the ward-wise distribution of manufacturing SMEs (in terms of frequency per ward) across the 31 wards of the city. The spatial analysis was performed using ArcGIS 10.1 and R statistical software package.

\section{STUDY AREA}

Khulna City Corporation (KCC) is located in the southwest region of Bangladesh along $89^{\circ} 28$ to $89^{\circ} 35^{\prime}$ ' east longitudes and $22^{\circ} 46^{\prime}$ to $22^{\circ} 54^{\prime}$ north latitudes on the banks of the river Rupsha and Bhairab. It is the third largest city with good connectivity to capital city Dhaka and other major districts of the country and part of India by road and railway. Khulna was declared as City Corporation in the year 1990 with an area of 45.65 square kilometres divided into 31 wards [28]. It has high economic significance as the regional capital of the southwest and the second port entry of the country. Historically Khulna is known as an industrial city due to the presence of different large and medium industries prominent among those include jute mills, paper mill, match factory, shrimp and frozen food processing, shipbuilding, sawmill and oxygen factories [29] although majority of the large industries were closed due to inefficiency and continued loss after independence. Currently, trade and service sectors dominate the economic activities of Khulna. Again Cottage, Small and Medium Enterprises (CSMEs) is the dominant category (99.91\%) while large enterprises constitute mere $0.09 \%$ among the economic establishments of Khulna district [30]. The focus of this study is on the manufacturing SMEs and their spatial pattern since they are considered as the main pathway to industrialization.

\section{SPATIAL PATTERN OF MANUFACTURING SMES KHULNA}

Varieties of small scale manufacturing industries operate in the city. A citywide survey of manufacturing SMEs, conducted in this study, could locate over 800 manufacturing SMEs which can be categorized into major five categories: i) light engineering and metal works, ii) timber and furniture, iii) bakery and food processing, iv) leather shoemaking and v) Agro-processing. SMEs beyond these categories were very few in numbers and hence not considered for mapping and analysis for this study. A brief description of the major sectors is presented in Table I.

The most of these firms fall under micro and small enterprises in terms of their number of employment and only a few are medium enterprises. Usually these SMEs collect raw materials from and sell their products in mostly local and within the country market. The firms are mostly located on rented spaces along the major transportation routes of the city, and on leased spaces from different government authorities like Bangladesh Railway and local government
Table I: Major manufacturing SME sector in Khulna Metropolitan city

\begin{tabular}{|c|c|c|}
\hline Sector & Types of firms & $\begin{array}{l}\text { Numbers } \\
\text { of firms } \\
\text { located }\end{array}$ \\
\hline $\begin{array}{l}\text { Light } \\
\text { engineering }\end{array}$ & $\begin{array}{l}\text { Metal fabrication } \\
\text { (metal window, doors } \\
\text { frame etc.), metal } \\
\text { furniture, machine } \\
\text { parts manufacturing } \\
\text { (lathes) and Bus body } \\
\text { making }\end{array}$ & 327 \\
\hline $\begin{array}{l}\text { Timber and } \\
\text { furniture }\end{array}$ & $\begin{array}{l}\text { Sawmill, wooden } \\
\text { furniture and van body } \\
\text { making }\end{array}$ & 288 \\
\hline $\begin{array}{l}\text { Bakery and food } \\
\text { processing }\end{array}$ & $\begin{array}{l}\text { Bakery and } \\
\text { confectionary items } \\
\text { manufacturing }\end{array}$ & 62 \\
\hline $\begin{array}{l}\text { Leather } \\
\text { shoemaking }\end{array}$ & Leather shoemaking & 30 \\
\hline Agro-processing & $\begin{array}{l}\text { Rice mill, flour mill, oil } \\
\text { mill, fish processing, } \\
\text { spice mills etc. }\end{array}$ & 81 \\
\hline Others & $\begin{array}{l}\text { Boutiques, toy making, } \\
\text { sanitary product } \\
\text { making, bamboo } \\
\text { basket, fence making, } \\
\text { jute bags and other } \\
\text { handicrafts items. }\end{array}$ & 33 \\
\hline
\end{tabular}

offices etc. within the city. These firms are usually labour oriented and use simple hand tools and small machineries.

Studies of location choices of SMEs suggest a variety of geo-economic factors like space availability, market access, access to raw materials, improved transport system, availability of utility, access to skilful labour, congenial climate, better community, and other services influence firms' location selection and agglomeration pattern in certain location [31], [32]. This study attempted to explore, by applying Kernel Density plot, whether there is any association between spatial agglomeration of each category of manufacturing SMEs and two important spatial variables proximity to major roads and proximity to rivers.

The result shows that all categories of SMEs tend to locate close to the major roads of the city. The density curve for each category of manufacturing SMEs tends to show peaks around 100 meters from the major roads of the city as observed in Fig.1. whereas in terms of proximity to rivers, different categories of SMEs demonstrate different spatial clustering patterns. The density plots shown in Fig. 2 show that leather shoemaking and bakery and food processing firms cluster in two locations as two peaks are observed in their respective density plots. Majority of the leather shoemaking firms cluster between 500 and 600 meter from the river and a smaller cluster locates at around 1100 meter distance from the river. 

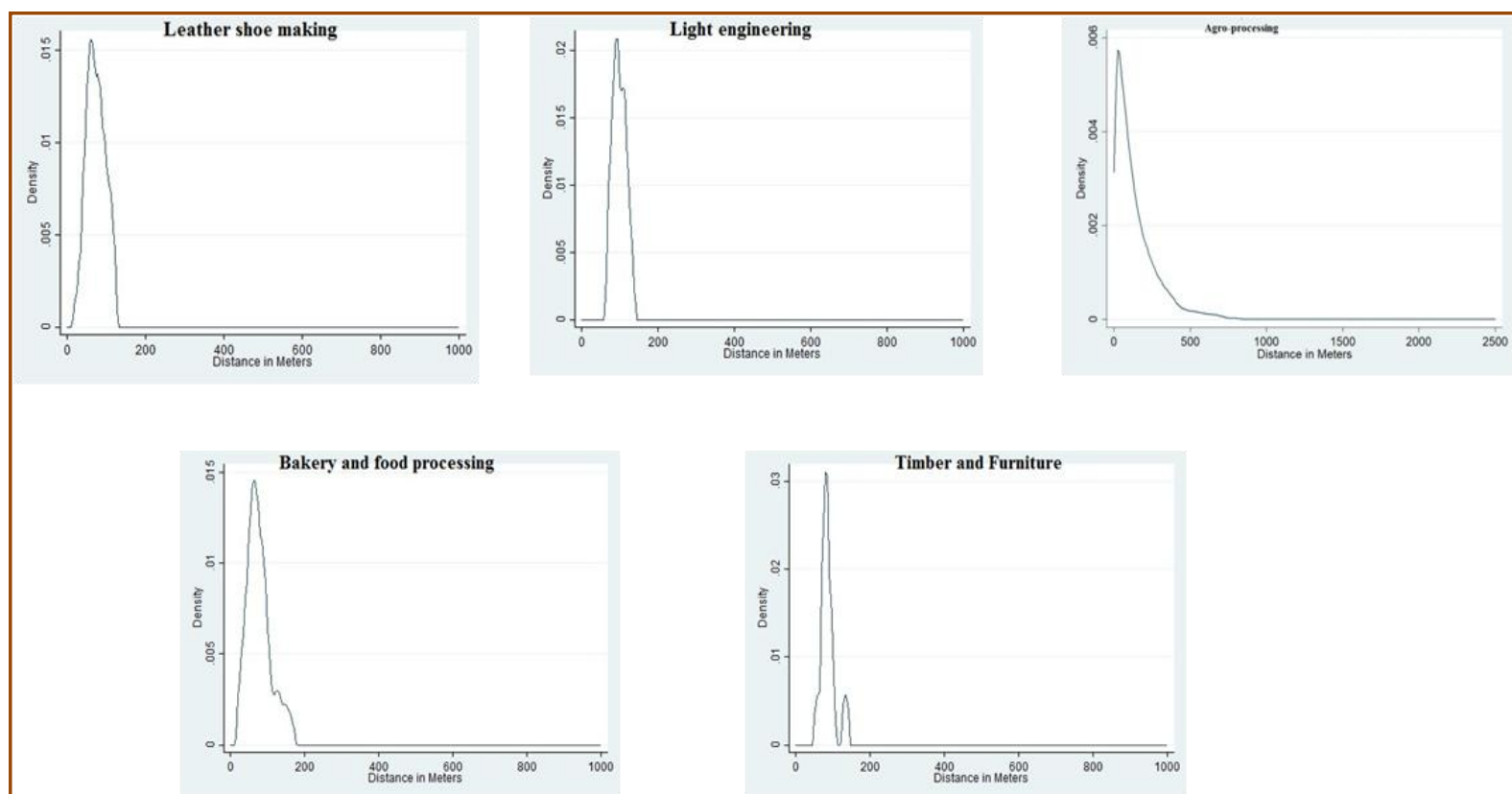

Fig. 1 Spatial cluster trends of the major manufacturing SMEs in relation to proximity to major city roads. X axes in the kernel density plot represent the distance in meters, while $\mathrm{Y}$ axes represent density of firms

In case of bakery and food processing SMEs, the larger cluster is located around between 500-700 meters distance and the smaller one is located between 1300 and 1400 meters from the river. The light engineering SMEs are found to cluster between 1200-1300 meters from the river. For agro-processing SMEs majority of the firms cluster between
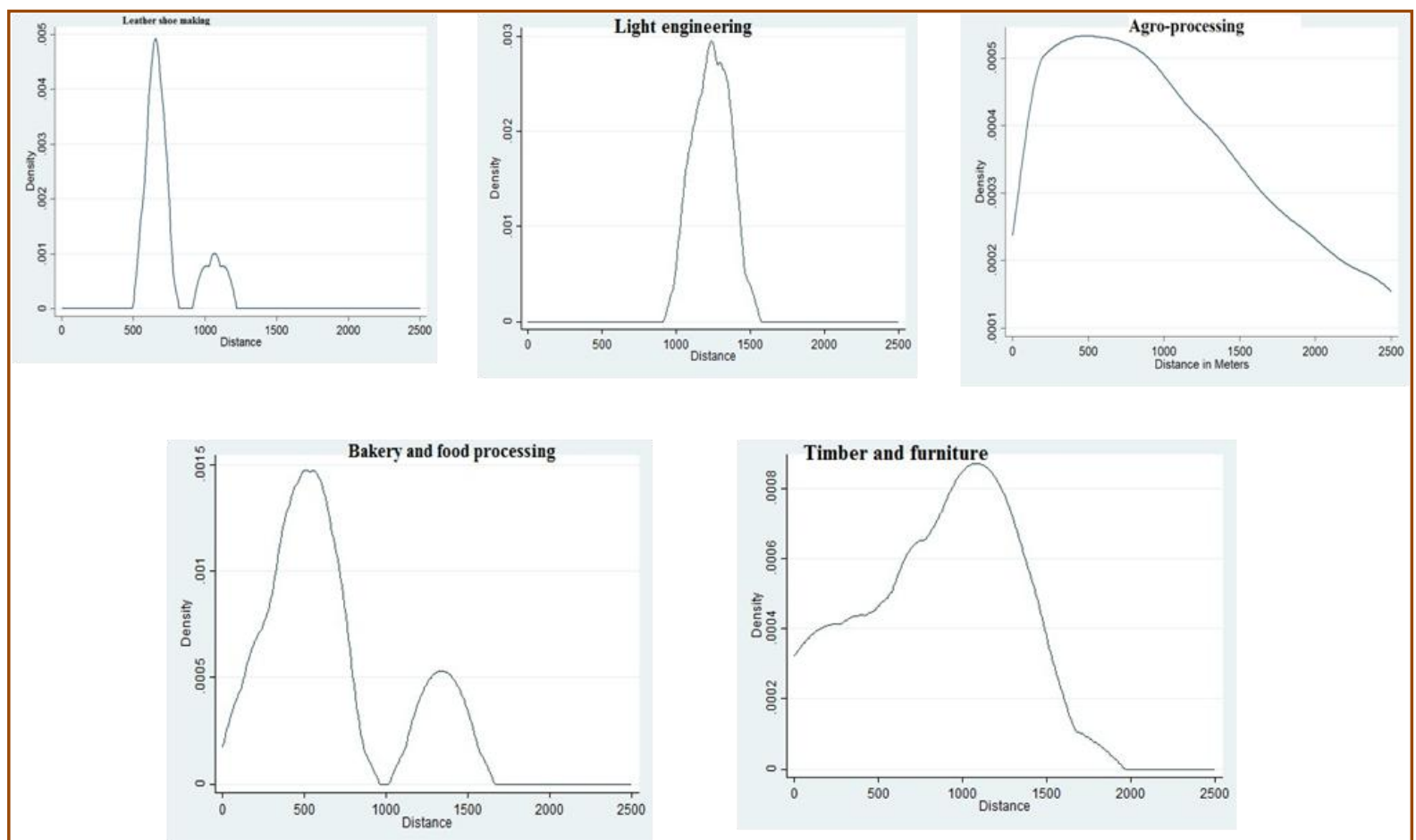

Fig. 2 Spatial cluster trends of the major manufacturing SMEs in relation to proximity to river. X-axes in the in the kernel density plot represent distance in meters while $\mathrm{Y}$-axes represent the density of firms 


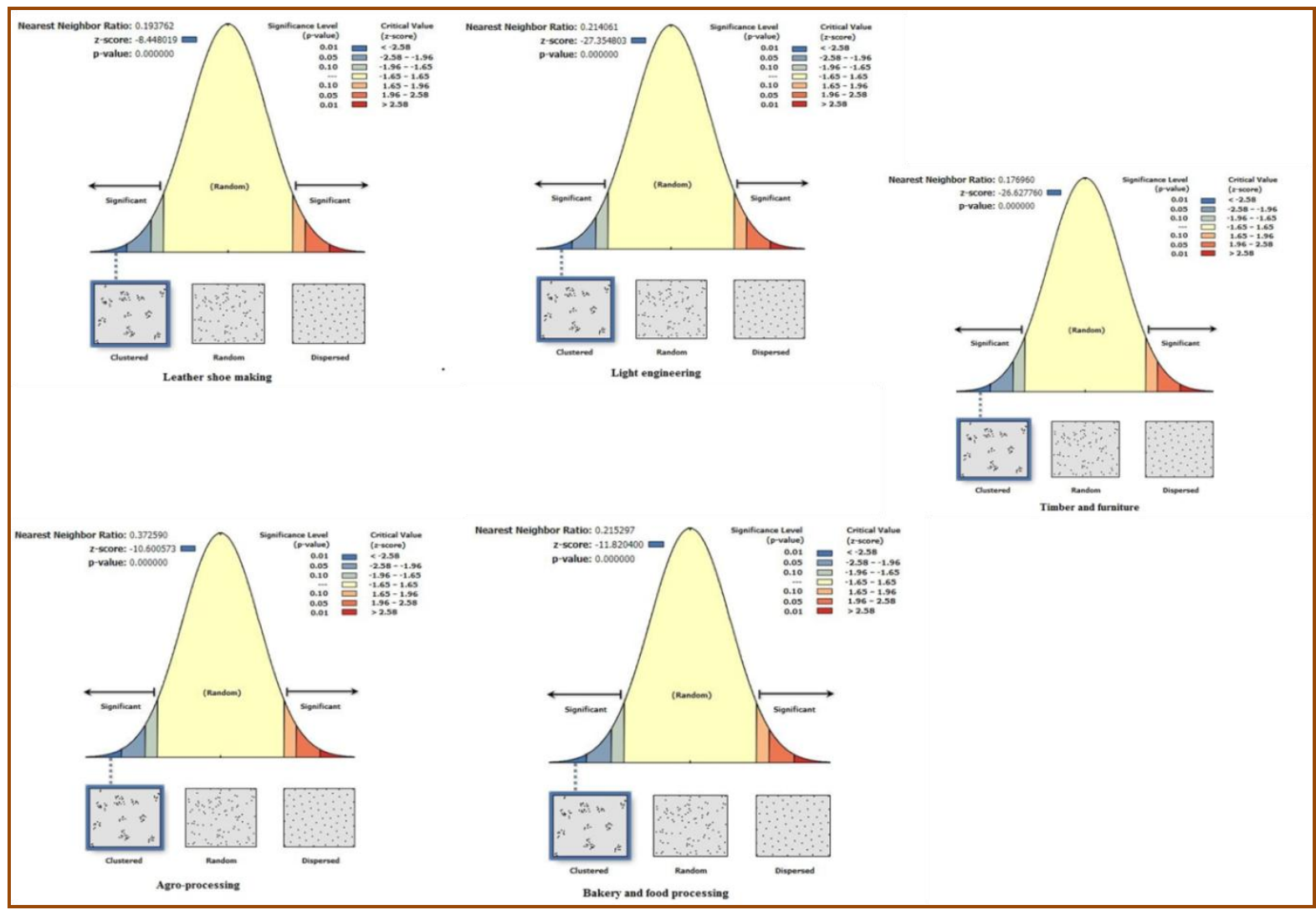

Fig. 3: Results of Average Nearest Neighbour Distance of Different categories of manufacturing SMEs in Khulna CV Corporation.

250 to 750 meters distance from river as indicated by the relatively flattened density curve between these ranges. Lastly, timber and furniture SMEs show an interesting pattern - the density curve gradually rises from very close to the river and peaks at around 1200 meters from the river. This pattern is evident since the majority of the sawmills are located at Labanchara and Rupsha Stand Road just beside the embankment of river Rupsha and most of the furniture workshops are scattered throughout the city area. Thus manufacturing SMEs in Khulna city tend to locate closer to major roads than to river.

The spatial distributions of the different categories of manufacturing SMEs were also explored by applying 'Average Nearest Neighbour ratio'. The results indicate each of the five categories of SMEs shows clustered pattern. The average nearest neighbour ratios for leather shoe making, light engineering, agro-processing, bakery and food processing and timber and furniture SMEs were 0.194, $0.214,0.372,0.215$ and 0.176 with $\mathrm{Z}$ scores of -8.448 , $-27.354,-10.600,-11.820$ and -26.627 respectively. All these ratios are statistically significant at $99 \%$ confidence level indicating that the null hypothesis "firms in all categories are distributed randomly" is rejected and thus firms show a clearly clustered pattern as shown in Fig. 3. This study further attempted to explore the overall spatial distribution pattern of the SMEs across the 31 wards of the city. The choropleth map in Fig. 4 shows that the firms are not evenly distributed among the wards. Ward number 21 and 30 have the highest (56-96 units) concentration of firms followed by ward number 16, 18, 19, 20, 22, 24, 26, 29 and 31 having 31-55 units of firms.

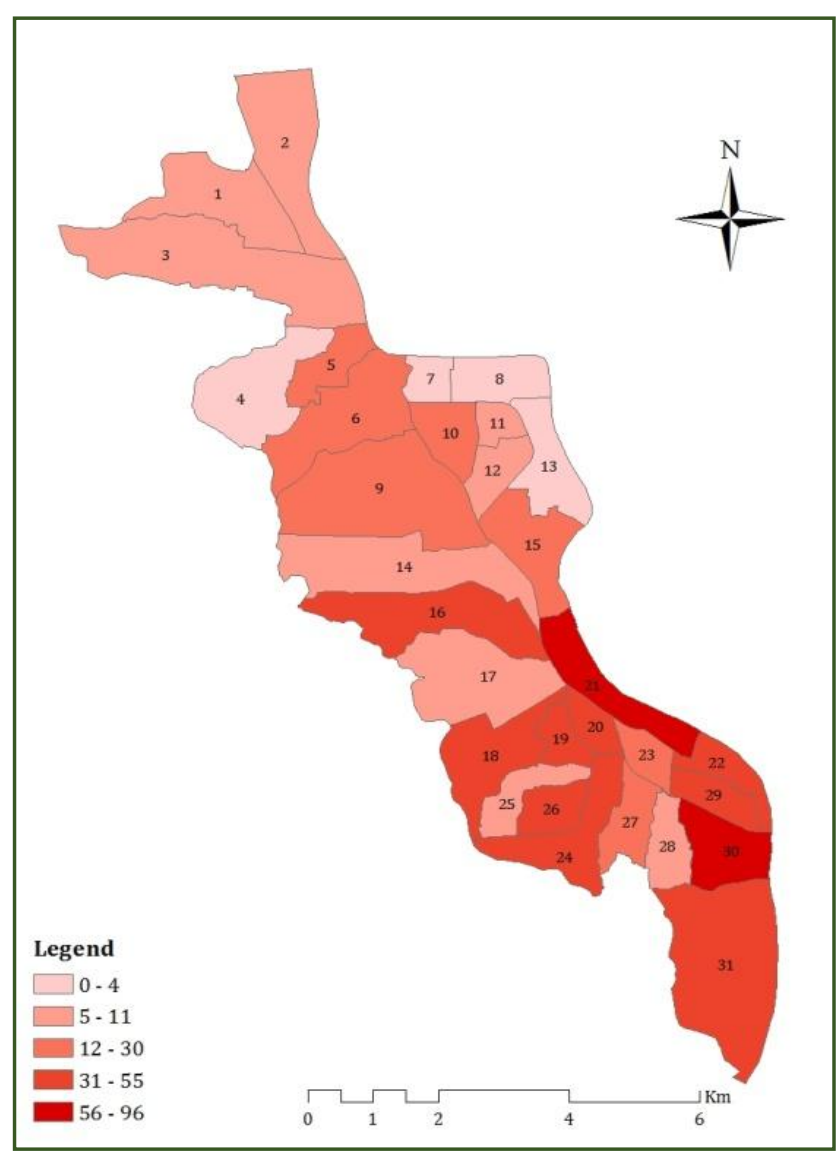

Fig. 4: Ward-wise distribution of manufacturing SMEs in Khulna City [33] 
The other wards have relatively less unit of manufacturing SMEs. Ward 21 is the central business point and administrative headquarter of the city. All types of small manufacturing SMEs especially light engineering, bakery, spice mills, and furniture workshops are located here more in numbers. Availability of low cost leased spaces from Bangladesh Railway Corporation, good connectivity through both railway and roads to all other cities, presence of the central wholesale market (Boro Bazar) as the source of raw materials, proximity to major financial institutions and above all large circulation of people may have influenced the clustering of firms in this ward. On the other hand, ward 30 possesses the largest cluster of timber and furniture. Most of the sawmills are located here due to availability of large open space on the embankment of river Rupsha. Wards 30 and 31 are also considered as the industrial zone of the city and well connected by roads and river to other parts of the city. Especially firms needing large space to operate like sawmills, rice mills, flour mills, and fish processing are found to locate on spaces adjacent to river Rupsha and spaces belong to the Bangladesh Railway Corporation due to availability of open spaces. Light engineering and furniture shops are found to locate all around the city but they are found to cluster along the major roads and spaces belong to the Bangladesh Railway Corporation.

\section{CONCLUSION}

The major manufacturing SMEs in Khulna City Corporation depict a clustered spatial pattern. All types of SMEs tend to cluster along the major roads of the city due to better connectivity and more circulation of people. Manufacturing SMEs requiring more spaces are found to cluster close to river banks. Further average nearest neighbourhood analysis shows that each category of SMEs tends to locate close to other similar firms indicating clusters. Moreover spatial distributions of SMEs in terms of numbers also show a clustered pattern across 31 wards of the city. Most number of firms agglomerates at few of the wards adjacent to central business, industrial and administrative zones of the city and represent the potential cluster regions (PCR) of the city. One thing needs to be considered that this study can be treated as partial since it only focused on spatial pattern analysis and did not explore the interrelations or joint actions among firms which are also important to define a business cluster. Yet the study would be helpful for the policymakers and city planners because it demonstrated the geographical concentration of firms i.e. whether a critical mass of firms exists or not, to be considered for implementing cluster-based development strategies. The study was conducted on manufacturing SMEs of Khulna city and similar studies can also be done for service and trade sectors and in other cities as well to find industry cluster for equitable regional development. For effective implementation of CBED further study can be conducted on to explore why firms cluster in certain locations and the interrelations among them.

\section{ACKNOWLEDGMENT}

The authors are thankful to Md. Kamal Hossain, Student, Masters Program, Urban and Rural Planning Discipline,
Khulna University, Bangladesh (Current position: GIS Assistant, Asian Disaster Preparedness Center) for his technical support with the ArcGIS software.

\section{REFERENCES}

[1] K. K. Sahu, "Urbanization and Growth Linkages in China," IOSR Journal of Humanities And Social Science, vol. 8, no. 6, pp. 1-10, 2013

[2] M. Chen, H. Zhang, W. Liu, and W. Zhang, "The global pattern of urbanization and economic growth: evidence from the last three decades," PloS one, vol. 9, no. 8, p. e103799, 2014.

[3] L. Narayan, "Urbanization and development," International Journal of Research, vol. 1, no. 8, pp. 901-908, 2014.

[4] H. M. N. Nguyen, L.D., "The relationship between urbanization and economic growth: An empirical study on ASEAN countries," International Journal of Social Economics, vol. 45, no. 2, pp. 316-339, 2018.

[5] M. E. Porter, "Clusters and the new economics of competition," Harvard Business Review vol. 76, no. 6, pp. 77-91, 1998.

[6] A. Cumbers and D. MacKinnon, "Introduction: clusters in urban and regional development," Urban Studies, vol. 41, no. 5/6, pp. 959-969, May 2004

[7] P. Li and X. Chen, "The urbanization of Chinese Midland and the development of SME," Chinese Business Review, vol. 4, no. 4, pp $16-21,2005$

[8] T. Tambunan, "Development of SME in ASEAN with Reference to Indonesia and Thailand," Chulalongkorn Journal of Economics, vol. 20, no. 1, pp. 53-83, 2008.

[9] V. Navickas and A. Malakauskaite, "The impact of clusterization on the development of small and medium-sized enterprise (SME) sector," Journal of Business Economics and Management, vol. 10, no. 3, pp. 255-259, 2009.

[10] B. Safavi and A. Bagheri, "The role of industrial cluster in order to create a competitive advantage for SMEs to achieve world-class manufacturing: The case of Khuzestan date cluster," Academic journal of research in business and accounting, vol. 2, pp. 11-13, 2014.

[11] C. H. Ketels and O. Memedovic, "From clusters to cluster-based economic development," International journal of technological learning, innovation and development, vol. 1, no. 3, pp. 375-392, 2008.

[12] A. Mikhaylov, "Information Technology Cluster in Kaliningrad Region: An Eternal Initiative or Launch Pad?," Social and Economic Geography, vol. 1, no. 1, pp. 16-22, 2015.

[13] N. Jote, B. Beshah, D. Kitaw, and A. Abraham, "AHP-based micro and small enterprises' cluster identification," in 2013 International Conference on Soft Computing and Pattern Recognition (SoCPaR), 2013, pp. 225-231.

[14] N. Reid, M. C. Carroll, B. W. Smith, and J. P. Frizado, "GIS and economic development," in Planning and Socioeconomic Applications, Geotechnologies and the Environment, J. D. a. J. Gatrell, R. R., Ed., ed: C Springer Science+Business Media B.V, 2009, pp. 5-27.

[15] M. M. Hassan, M. S. Alenezi, and R. Z. Good, "Spatial pattern analysis of manufacturing industries in Keraniganj, Dhaka, Bangladesh.," GeoJournal, pp. 1-15, doi:https://doi.org/10.1007/s10708-018-9961-5

[16] Bangladesh Economic Review, ed: Economic Adviser's Wing, Finance Division, Ministry of Finance, Government of the People's Republic of Bangladesh 2018.

[17] General Economics Division, "Seventh five year plan FY 2016-2020 Accelerating growth, empowering citizens," B. P. C. GED, Ed., ed, 2015.

[18] J. Swords, "Michael Porter's cluster theory as a local and regional development tool: The rise and fall of cluster policy in the UK," Local Economy, vol. 28, no. 4, pp. 369-383, 2013.

[19] J. Cortright, Making sense of clusters: Regional competitiveness and economic development: Brookings Institution, Metropolitan Policy Program, 2006.

[20] M. Albaladejo, Determinants and policies to foster the competitiveness of SME clusters: Evidence from Latin America: Queen Elizabeth House Oxford, 2001.

[21] S. A. Rosenfeld, "Bringing business clusters into the mainstream of economic development," European planning studies, vol. 5, no. 1, pp. 3-23, 1997.

[22] M. E. Porter, "Location, competition, and economic development: Local clusters in a global economy," Economic development quarterly, vol. 14, no. 1, pp. 15-34, 2000. 
[23] V. Prasannakumar, H. Vijith, R. Charutha, and N. Geetha, "Spatio-temporal clustering of road accidents: GIS based analysis and assessment," Procedia-Social and Behavioral Sciences, vol. 21, pp. 317-325, 2011.

[24] D. Kim and H. Lee, "Crime trend analysis by changes of spatial autocorrelation and hot-spot," in Proc. of the 2016 Int. Conf. on Industrial Engineering and Operations Management Kuala Lumpur, Malaysia, Mar. 6-10, 2016, pp.1854-1865.

[25] A. S. Mohaymany, M. Shahri, and B. Mirbagheri, "GIS-based method for detecting high-crash-risk road segments using network kernel density estimation," Geo-spatial Information Science, vol. 16, no. 2, pp. 113-119, 2013.

[26] Bangladesh Bank, "Master circular on SME Financing (SMESPD 4)," SME and Special Programs Department, Bangladesh Bank, Dhaka2015.

[27] ESRI. (2018). How Average Nearest Neighbor Distance (Spatial Statistics) works Available: http://www.esri.com

[28] Khulna City Corporation. (No Date, February 20, 2019). Basic statistics. Available:

www.khulnacity.org/Content/index.php?page=About_KCC\&bGs\&pid= $\underline{30}$

[29] BBS, "District Statistics 2011: Khulna," S. a. I. D. (SID), Ed., ed Ministry of Planning Government of the People's Republic of Bangladesh 2013.

[30] BBS, "Economic Census 2013: District Report Khulna," S. a. I. D. (SID), Ed., ed: Ministry of Planning Government of the People's Republic of Bangladesh, 2016.

[31] E. Van Noort and I. Reijmer, Location choice of SMEs: The most important determinants: EIM, Small Business Research and Consultancy, 1999.

[32] J. Martyniuk-Pęczek, O. Martyniuk, A. Gierusz, and G. Pęczek, "Determinants of SME location in a suburban area: Evidence from the Gdańsk-Gdynia-Sopot metropolitan area," Urbani izziv, vol. 28, pp. 122-134, 2017.

[33] S. M. T. Rahman and A. Kabir, "Do manufacturing small and medium enterprises cluster geographically in Khulna city: - A spatial analysis", Asia Proc. of Social Sciences, vol. 4, no. 1, pp. 28-31, 2019.

\section{AUTHORS PROFILE}

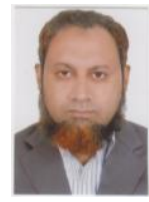

S M Towhidur Rahman is currently serving as faculty member at Business Administration Discipline of Khulna University, Bangladesh. He obtained his MBA from University of Dhaka. Currently he is pursuing his doctoral degree in Urban and Rural Planning Discipline of Khulna University. His research interest includes SME, industry cluster, agglomeration economies and regional development.

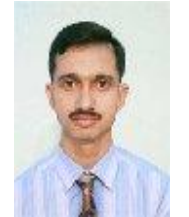

Professor Ahsanul Kabir is a physical planner by training with an interest to optimize resource allocation. He received his Doctor of Philosophy from University of New South Wales, Australia. As a faculty of Urban and Rural Planning Discipline at Khulna University, Bangladesh, Prof. Kabir emphasizes on the strategic planning issues and explores for spatial interaction between urban and rural area. He has focus on the agglomeration of economies and spatial interaction between them Prof. Kabir has supervised several postgraduate researches on spatial dynamics of urbanization 